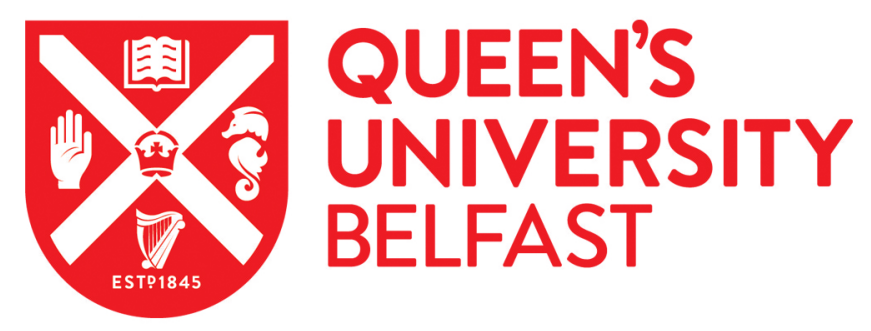

\title{
Silicon Photoanodes for Solar-Driven Oxidation of Brine: A Nanoscale, Photo-Active Analog of the Dimensionally-Stable Anode
}

O'Rourke, C., Tang Kong, R., Mills, A., \& McIntyre, P. C. (2018). Silicon Photoanodes for Solar-Driven Oxidation of Brine: A Nanoscale, Photo-Active Analog of the Dimensionally-Stable Anode. Journal of the Electrochemical Society, 165(16), H1072-H1079. https://doi.org/10.1149/2.0791816jes

Published in:

Journal of the Electrochemical Society

Document Version:

Peer reviewed version

Queen's University Belfast - Research Portal:

Link to publication record in Queen's University Belfast Research Portal

Publisher rights

Copyright 2018 Electrochemical Society. This work is made available online in accordance with the publisher's policies. Please refer to any applicable terms of use of the publisher.

\section{General rights}

Copyright for the publications made accessible via the Queen's University Belfast Research Portal is retained by the author(s) and / or other copyright owners and it is a condition of accessing these publications that users recognise and abide by the legal requirements associated with these rights.

Take down policy

The Research Portal is Queen's institutional repository that provides access to Queen's research output. Every effort has been made to ensure that content in the Research Portal does not infringe any person's rights, or applicable UK laws. If you discover content in the Research Portal that you believe breaches copyright or violates any law, please contact openaccess@qub.ac.uk. 


\section{Silicon Photoanodes for Solar-Driven Oxidation}

\section{2 of Brine: A Nanoscale, Photo-Active Analog of}

\section{3 the Dimensionally-Stable Anode}

4 Robert Tang-Kong ${ }^{\mathrm{a}, \dagger}$, Christopher O'Rourke ${ }^{\mathrm{b}, \dagger}$, Andrew Mills $^{\mathrm{b}}$, and Paul C. McIntyre ${ }^{\mathrm{a} *}$

5 a: Department of Materials Science \& Engineering, Stanford University, California 94305, USA

6 b: Department of Chemistry and Chemical Engineering, Queens University Belfast, Stranmillis Road,

7 Belfast, BT9 5AG, UK

$8 \uparrow$ These authors contributed equally to this work

$9 \quad *$ e-mail: pcm1@,stanford.edu 


\section{Abstract}

12 We report the first results in which $\mathrm{ALD}-\mathrm{TiO}_{2}$ layers electronically couple silicon to an overlying 13 catalyst coating while inhibiting corrosion during brine splitting, a reaction that is capable of 14 generating not only a fuel $\left(\mathrm{H}_{2}\right)$ but also a disinfectant $\left(\mathrm{Cl}_{2}\right.$ or $\left.\mathrm{NaOCl}\right)$. An n-type silicon photoanode, 15 and a p+-silicon anode are protected by a $1.7 \mathrm{~nm}$ coating of amorphous $\mathrm{TiO}_{2}$ and $2 \mathrm{~nm}$ coating of Ir. 16 The $\mathrm{p}+-\mathrm{Si} / \mathrm{TiO}_{2} / \mathrm{Ir}$ anode is able to effect the oxidation of chloride $\left(0.5 \mathrm{M} \mathrm{H}_{2} \mathrm{SO}_{4}, 3.5 \mathrm{M} \mathrm{NaCl}\right)$ in the 17 dark with a low overpotential compared to that for oxidation of water $\left(0.5 \mathrm{M} \mathrm{H}_{2} \mathrm{SO}_{4}\right)$. The $0.294 \mathrm{~V}$ 18 overpotential difference occurs despite the difference in standard redox potentials, $\Delta \mathrm{E}=\left(\mathrm{E}^{\mathrm{o}}\left(\mathrm{Cl}_{2} / \mathrm{Cl}^{-}\right)\right.$$\left.19 \mathrm{E}^{\mathrm{O}}\left(\mathrm{O}_{2} / \mathrm{H}_{2} \mathrm{O}\right)\right)$, is $130 \mathrm{mV}$. Under 1 sun irradiation a photovoltage of $c a .0 .566 \mathrm{~V}$ is achieved by 20 comparing the illuminated $\mathrm{n}-\mathrm{Si} / \mathrm{TiO}_{2} / \mathrm{Ir}$ photoanode with the dark $\mathrm{p}+$-silicon anode. Although the $\mathrm{n}$ $21 \mathrm{Si} / \mathrm{TiO}_{2} / \mathrm{Ir}$ photoanode is only one half of an eventual tandem cell needed for photosynthetic brine 22 splitting, its ABPE for chloride oxidation is $1.42 \%$, ca. 28 times that for water oxidation. The 23 illuminated $\mathrm{n}$-Si/ $\mathrm{TiO}_{2} / \mathrm{Ir}$ photoanode remained stable at $1 \mathrm{~mA} \mathrm{~cm}^{-2}$ during a six-day chronopotentiometry test.

26 Key words: silicon; anode; brine; chloride; oxidation; photoelectrochemistry 


\section{Introduction}

Conversion of solar to electrical energy using photovoltaic devices, such as the silicon solar cell is well-established, but solar energy is diurnal and intermittent and so there is least of it when we most need it, i.e. at night in winter. As a consequence, there is great interest in developing efficient, inexpensive and stable solar energy conversion devices that generate readily utilizable chemical fuels. ${ }^{1,2}$ A popular, current approach is to develop a solar-driven, water-splitting system, since it uses the sun's energy to produce hydrogen, which can be stored, readily transported and used when needed. ${ }^{2}$ However, the overpotential for water oxidation, using the best platinum group metal electrocatalysts ${ }^{1}$, is still typically $300-400 \mathrm{mV}$ at $10 \mathrm{~mA} \mathrm{~cm}^{-2}$ and so represents a major barrier to the creation of a long-lasting, high solar to chemical energy efficiency device.

Recently, Nocera et al. suggested that an inexpensive artificial leaf water splitting device will find initial and widespread application in the developing world at less urbanized, off-the-grid, locations. ${ }^{3,4}$ Advantages of such photoelectrochemical cells (PEC's) which combine light absorption and catalyzed electrochemical reactions are 1) the potential simplicity of an integrated design, 2) their compact footprint and 3) their ability to accommodate less expensive catalysts operating at electrolysis current densities better matched to solar photocurrent densities.

Compared to the photocleavage of water, the photo-electrolysis of brine has not been studied nearly as widely, despite the fact that the overpotential for chlorine production is low. ${ }^{5}$ In addition, the electrolysis of salt water: (i) generates $\mathrm{H}_{2}$, alkali and $\mathrm{Cl}_{2}$, (or, $\mathrm{H}_{2}$ and $\mathrm{NaOCl}$, if the $\mathrm{Cl}_{2}$ and caustic are allowed to combine), (ii) stores approximately the same amount of energy per electron as the water splitting reaction, and (iii) generates a more valuable chemical oxidant feedstock, namely, $\mathrm{Cl}_{2}$ or $\mathrm{NaOCl}$. However, it is not without its challenges, given the oxidation of chloride to chlorine in acid solution

$$
2 \mathrm{Cl}^{-} \rightleftharpoons 2 \mathrm{Cl}_{2}+2 \mathrm{e}^{-}
$$

has a significantly higher standard redox potential $\left(\mathrm{E}^{\circ}\left(\mathrm{Cl}_{2} / \mathrm{Cl}^{-}\right)=1.36 \mathrm{~V}\right)$ than that of water

$$
\mathrm{H}_{2} \mathrm{O} \rightleftharpoons 2 \mathrm{H}^{+}+1 / 2 \mathrm{O}_{2}+2 \mathrm{e}^{-}
$$


$54\left(\mathrm{E}^{\mathrm{o}}\left(\mathrm{O}_{2} / \mathrm{H}_{2} \mathrm{O}\right)=1.23 \mathrm{~V}\right)$. Moreover, chlorine is a very aggressive oxidant, with a solubility in water $55\left(0.092 \mathrm{~mol} \mathrm{dm}^{-3} \mathrm{~atm}^{-1}\right)$ that is over $70 \mathrm{x}$ 's that of $\mathrm{O}_{2}$, thus increasing markedly the likelihood of its 56 reaction with cell components, including, most importantly, the semiconductor photoanode.

57 The industrial production of $\mathrm{Cl}_{2} / \mathrm{NaOCl}$ from brine is worth currently $\$ 46 \mathrm{Bn}$ in the USA alone. ${ }^{6}$ Its role in disinfection is important, since the need for potable (i.e. disinfected) water worldwide is great, with a sixth of the world population (ca. 1.1 Bn people) having no access to improved water supplies and with a much greater number consuming contaminated water every day. It is estimated that $>$ 4000 children die of diarrhoea alone every day due to poor water quality. ${ }^{7}$ There is, therefore, a compelling need for an inexpensive and compact solar-to-chemical energy conversion device capable of producing not only a fuel (hydrogen), for heating and for electricity (via a fuel cell), when the sun is not shining, but also a disinfectant - such as chlorine/hypochlorite - for use in generating potable water and clean surfaces.

Herein we report a silicon photoanode which functions both as a nanoscale version of the dimensionally-stable anode (DSA) ${ }^{8}$, the key technology in industrial chlor-alkali electrochemistry, and as an efficient absorber of solar light. This photoanode could function as a key junction in a multi-junction photoelectrochemical cell ${ }^{9}$ for unassisted brine splitting. Industrial DSA electrodes have a high precious metal (Ir, Ru) loading and thick active layers ${ }^{10}$ mixed with $\mathrm{TiO}_{2}$ and typically coating a Ti substrate. ${ }^{11,12}$ However, such anodes typically operate at current densities that are $100 \mathrm{x}$ 's greater than those (ca. $10 \mathrm{~mA} \mathrm{~cm}{ }^{-2}$ ) expected in any photosynthetic solar cell and In the reported nanoscale DSA structure, atomic layer deposited $\mathrm{TiO}_{2}$ is used to achieve stable brine splitting on silicon, which is otherwise unstable under the conditions used in chloride oxidation. The $\mathrm{TiO}_{2}$ thin film electronically couples an overlying chloride oxidation catalyst film, in the form of an ultra-thin iridium layer, to the silicon substrate, achieving a high yield for chlorine synthesis, photovoltages exceeding $560 \mathrm{mV}$ and greater than 6 days of continuous operation during chronoamperometry testing.

\section{Experimental}


The silicon wafers used here were either: (i) heavily boron-doped $\mathrm{p}^{+}$-type $\mathrm{Si}(100)$ wafers $(\rho=0.001-$ $0.002 \Omega \mathrm{cm}, 500 \mu \mathrm{m}$ thick), which were used as conductive silicon substrates to study water and chloride oxidation in the dark or (ii) lightly phosphorous-doped, n-type $\operatorname{Si}(100)$ wafers $(\rho=0.1-0.2$ $\Omega \mathrm{cm}, 500 \mu \mathrm{m}$ thick $)$. The wafers were used as received, with a thin $(<2 \mathrm{~nm}) \mathrm{SiO}_{2}$ layer as prepared by the wafer supplier, Nova Electronic Materials. Onto both wafer types, a $1.7 \mathrm{~nm}$ amorphous $\mathrm{TiO}_{2}$ layer was deposited via 30 cycles of atomic layer deposition, $\mathrm{ALD}$, at $170^{\circ} \mathrm{C}$ with tetrakisdimethylamido titanium, TDMAT, as the titanium source and $\mathrm{H}_{2} \mathrm{O}$ as the oxygen source. In all cases, this was followed by a coating of a $2 \mathrm{~nm}$ Ir layer, deposited by electron beam evaporation. The backside contacts for the $\mathrm{n}-\mathrm{Si}$ and $\mathrm{p}^{+}-\mathrm{Si}$ substrates were e-beam evaporated $\mathrm{Al}$ and $\mathrm{Pt}$, respectively. These two electrodes are referred to throughout as $\mathrm{n}-\mathrm{Si} / \mathrm{TiO}_{2} / \mathrm{Ir}$ and $\mathrm{p}+-\mathrm{Si} / \mathrm{TiO}_{2} / \mathrm{Ir}$ electrodes. A schematic of the $\mathrm{n}-\mathrm{Si} / \mathrm{TiO}_{2} / \mathrm{Ir}$ photoanode used in this work for the photoelectrolysis of acidified brine is illustrated in Figure 1.

\section{Methods}

All electrochemical and photoelectrochemical experiments were conducted using $0.5 \mathrm{~mol} \mathrm{dm}^{-3} \mathrm{H}_{2} \mathrm{SO}_{4}$, in the absence (for water oxidation) and presence (for chloride oxidation) of $3.5 \mathrm{~mol} \mathrm{dm}^{-3} \mathrm{NaCl}$. All electrochemical work was performed using a modified version of the 'silo-like' electrochemical cell used by the McIntyre and Chidsey group, ${ }^{13}$ which is illustrated in Figure S1. The cell components and design are described in the supporting information. The gas inlet and outlet of the cell were used in $\mathrm{Cl}_{2}$ yield measurements to sweep out, using a continuous stream of $\mathrm{Ar}$ (flow rate: $100 \mathrm{~cm}^{3} \mathrm{~min}^{-1}$ ), the $\mathrm{Cl}_{2}$ generated in the electrochemical cell into a $100 \mathrm{~cm}^{3} \mathrm{KI}$ trap the spectrophotometric analysis of the latter allowed the total amount of $\mathrm{Cl}_{2}$ to be assessed ${ }^{14}$. The bulk of the electrochemical measurements were conducted using a Metrohm Autolab (PGSTAT128N) potentiostat. All linear sweep voltammograms, LSVs, were recorded using a $1 \mathrm{mV} \mathrm{s}^{-1}$ sweep rate. Electrochemical impedance spectroscopy was performed using a FRA32M module (Metrohm) in order to determine the resistance of electrolytes used in this study and so compensate for the $i \mathrm{R}$ drop in the cell. 
A sealed, quartz window recessed in the PTFE cap of the electrochemical cell allowed the flat, n$\mathrm{Si} / \mathrm{TiO}_{2} / \mathrm{Ir}$ anode, installed in the base of the cell, to be irradiated. Irradiations were conducted using either: (i) a high power $455 \mathrm{~nm}$ LED (HBW = $16 \mathrm{~nm}$; OSLON+ PowerStar Deep Blue $455 \mathrm{~nm}$; maximum wattage $>2.2 \mathrm{~W}$ ) providing an irradiance of ca. $6.5 \mathrm{~mW} \mathrm{~cm}^{-2}$ (at ca. $7 \mathrm{~cm}$ above the electrode) for the chronopotentiometry experiments or, more usually, (ii) a $150 \mathrm{~W}$ solar simulator (Sciencetech SS150W) fitted with a AM1.5 filter, simulating the irradiance of 1 sun (ca. $100 \mathrm{~mW} \mathrm{\textrm {cm } ^ { - }}$ ${ }^{2}$, measured using a power meter, ThorLabs, PM100D). All UV/Vis spectra were recorded using an Agilent Cary 6000i UV/Vis/NIR spectrophotometer. IPCE measurements were made using a standard glass vial (A-001056, Biologic) with a PTFE cap holding all electrodes in place and a1kW Xe-arc lamp (OBB KiloArc), coupled to a $200 \mathrm{~mm}$ meter Czerny-Turner monochromator (OBB), and Gooch \& Housego (OL756) radiometer were used to provide the monochromatic light and associated irradiance values, respectively. IPCE measurements were conducted on a n-Si/ $\mathrm{TiO}_{2} / \mathrm{Ir}$ photoanode (area: $0.8 \mathrm{~cm}^{2}$ ) polarised at $1.8 \mathrm{v}$ vs NHE in an electrolyte volume of $15 \mathrm{~mL}\left(0.5 \mathrm{M} \mathrm{H}_{2} \mathrm{SO}_{4}+3.5 \mathrm{NaCl}\right)$.

\section{Results and Discussion}

\section{Optical measurements and initial photoelectrochemical studies}

Silicon, a candidate material for the low-gap semiconductor of a tandem device, has a band gap of 1.1 $\mathrm{eV}$ and so absorbs strongly incident light of $\lambda \leq 1127 \mathrm{~nm}$, as indicated by its reflectance spectrum which has been widely reported..$^{15}$

In contrast to the absorption spectrum of $\mathrm{Si}$, those of the protecting Ti oxide and the Ir film used in this work have not been reported previously. Thus, the UV/Vis/NIR absorption spectrum of the thin $(1.7 \mathrm{~nm}) \mathrm{TiO}_{2}$ film, deposited using ALD on quartz, is illustrated in Figure 2and shows that it absorbs no visible light, i.e. it is colourless, and that it absorbs very little UV radiation. Thus, its presence will have very little effect on the amount of light absorbed by the underlying $\mathrm{Si}$. In contrast, the absorption spectrum of the $2 \mathrm{~nm}$ Ir film, also illustrated in Figure 2, reveals an average absorbance of ca. 0.184 throughout the visible and NIR spectrum, which suggests that only ca. $65.5 \%$ of the incident visible light is transmitted by the Ir film to the underlying Si. Thus, although the deposition 
of an Ir film is convenient and relatively easy to effect, the use of the Ir catalyst in the form of a continuous film reduces the efficiency of the photoanode significantly by partly obscuring the surface of the Si. This implies that the photocurrent may be improved markedly if a pattern of catalyst islands is used instead of a film. This approach has been adopted in the work of $\mathrm{Hu}$ et al ${ }^{16}$ who used $100 \mathrm{~nm}$ thick Ni-island electrocatalysts patterned in square arrays of $3 \mu \mathrm{m}$ diameter circles on a $7-\mu \mathrm{m}$ pitch, to cover thick (44 nm), but 'electronically leaky', $\mathrm{TiO}_{2}$ protective coatings on an n-Si photoanode film, so that the islands only blocked $14.4 \%$ of the electrode surface.

In order to quickly compare and contrast the efficacies of the $\mathrm{n}-\mathrm{Si} / \mathrm{TiO}_{2} / \mathrm{Ir}$ photoanode for water oxidation (in $0.5 \mathrm{M} \mathrm{H}_{2} \mathrm{SO}_{4}$ ) to that of chloride (in $0.5 \mathrm{M} \mathrm{H}_{2} \mathrm{SO}_{4}$ plus $3.5 \mathrm{M} \mathrm{NaCl}$ ), cyclic voltammograms photocurrents were recorded under 1 sun irradiation and the results of this work are illustrated in Figure 4.

Inspection of the results reveals that $\mathrm{n}-\mathrm{Si} / \mathrm{TiO}_{2} / \mathrm{Ir}$ photoanode is able to effect the photo-oxidation of chloride to chlorine in acid at lower potentials (typically, ca. $300 \mathrm{mV}$ lower at $1 \mathrm{~mA} \mathrm{~cm}{ }^{-2}$ ) than that for water oxidation, despite the fact that $\Delta \mathrm{E}=\left(\mathrm{E}^{\mathrm{o}}\left(\mathrm{Cl}_{2} / \mathrm{Cl}^{-}\right)-\mathrm{E}^{\mathrm{o}}\left(\mathrm{O}_{2} / \mathrm{H}_{2} \mathrm{O}\right)\right)=130 \mathrm{mV}$. This feature results from the much higher overpotential for water oxidation, $\eta_{\mathrm{O} 2},\left(\eta_{\mathrm{O} 2} \approx 0.428 \mathrm{~V}\right.$ on a $\mathrm{p}+-\mathrm{Si} / \mathrm{TiO}_{2} / \mathrm{Ir}$ anode, vide infra) compared to that for chloride oxidation $\left(\eta_{\mathrm{Cl} 2} \approx\right.$ ca. $0.134 \mathrm{~V}$ on a $\mathrm{p}+-\mathrm{Si} / \mathrm{TiO}_{2} / \mathrm{Ir}$ anode, vide infra).

In contrast, in $1 \mathrm{M} \mathrm{NaOH}$, the primary chloride oxidation reaction is:

$$
\mathrm{Cl}^{-}+2 \mathrm{OH}^{-} \rightleftharpoons \mathrm{OCl}^{-}+2 \mathrm{H}_{2} \mathrm{O}+2 \mathrm{e}^{-}
$$

where, $\left(\mathrm{E}^{\mathrm{o}}\left(\mathrm{OCl}^{-} / \mathrm{Cl}^{-}\right)=0.81 \mathrm{~V}\right.$ vs NHE, so that $\Delta \mathrm{E}$, now equal to: $\left(\mathrm{E}^{\mathrm{o}}\left(\mathrm{OCl}^{-} / \mathrm{Cl}^{-}\right)-\mathrm{E}^{\mathrm{o}}\left(\mathrm{O}_{2} / \mathrm{OH}^{-}\right)\right.$, is much larger $(406 \mathrm{mV})$, than the $130 \mathrm{mV}$ in acid, and this mostly off-sets the benefit gained by having $\eta_{\mathrm{C} 12}$ $<<\eta_{\mathrm{O} 2}$. Thus, in $1 \mathrm{M} \mathrm{NaOH}$ the $\mathrm{CV}$ curves for water and chloride oxidation are no longer well separated, but overlap, so that the photoanode generates a mixture of hypochlorite and $\mathrm{O}_{2}$. As a consequence, in order to simplify this study to that of either water or chloride oxidation, but not a mixture of both, the bulk of the work described here was carried out under acidic conditions $(0.5 \mathrm{M}$ $\mathrm{H}_{2} \mathrm{SO}_{4}$ ) with or without $3 \mathrm{M} \mathrm{NaCl}$. In acidified brine the overall photo-electrochemical reaction is the 
oxidation of chloride to $\mathrm{Cl}_{2}$, i.e. reaction (1), at the $\mathrm{n}-\mathrm{Si} / \mathrm{TiO}_{2} / \mathrm{Ir}$ photoanode, and the concomitant reduction of $\mathrm{H}^{+}$to $\mathrm{H}_{2}$ at the $\mathrm{Pt}$ counter electrode, as illustrated in Figure 1.

It can be shown ${ }^{13}$ that solar irradiation at 1 sun provides ca. $2.7 \times 10^{17}$ photons $\mathrm{cm}^{-2}$ with energies $\geq$ the Si band gap, which in turn should produce a theoretical maximum photocurrent density of ca. $43 \mathrm{~mA}$ $\mathrm{cm}^{-2}$. From the results illustrated in Figure 4, the light-limited saturation currents for both water and chloride oxidation, achieved at high bias potentials, were found to be ca. $31 \mathrm{~mA} \mathrm{~cm}^{-2}$, i.e. ca. $72 \%$ of the theoretical maximum. Given that ca. $35 \%$ of the incident light is obscured by the Ir film, the value of $72 \%$ implies that, at high bias potentials, the $\mathrm{n}-\mathrm{Si} / \mathrm{TiO}_{2} / \mathrm{Ir}$ photoanode, is ca. $100 \%$ efficient in converting photons to current, i.e. the photogenerated holes are readily and efficiently conducted through the $\mathrm{TiO}_{2}$ overlayer to the Ir electrocatalyst. IPCE measurements were also made using the n$\mathrm{Si} / \mathrm{TiO}_{2} / \mathrm{Ir}$ photoanode biased at $1.8 \mathrm{~V}$ vs NHE (Figure 4). The IPCE is high, across a wide range of wavelengths, and consistent with the average value of $72 \%$ reported above, suggesting that, once corrected for the absorbance due to the catalyst layers, this system, with its $1.8 \mathrm{~V}$ bias is ca. $100 \%$ efficient in converting photons to current.

The broken vertical lines in Figure 4 represent the thermodynamic redox potentials for water (black) and chloride (red) oxidation in $0.5 \mathrm{M} \mathrm{H}_{2} \mathrm{SO}_{4}$ and in both photo-electrochemical reactions, reasonable (up to $10 \mathrm{~mA} \mathrm{~cm}^{-2}$ and $1 \mathrm{~mA} \mathrm{~cm}$-2 for $\mathrm{Cl}^{-}$and $\mathrm{H}_{2} \mathrm{O}$ oxidation, respectively) photocurrents are generated, by the $\mathrm{n}-\mathrm{Si} / \mathrm{TiO}_{2} / \mathrm{Ir}$ photoanode at 1 sun illumination, at potentials at and below these thermodynamic limits, suggesting a reasonable degree of solar to chemical energy conversion, although clearly much more so for chloride oxidation. However, as we shall see later, a useful assessment of the applied bias photon efficiency, ABPE, requires the cell to be operated in 2electrode, rather than 3-electrode mode, and under such conditions the efficiency of cell is significantly reduced.

The above results show that, upon band gap illumination of the $\mathrm{n}-\mathrm{Si}$, the photogenerated holes in the Si valence band are able to move through the intermediate oxide layers, as illustrated in Figure 1, to the Ir layer, where they are then able to oxidize surface adsorbed water, or chloride, from the electrolyte solution. Further work on $\mathrm{TiO}_{2}$-protected $\mathrm{Si}$ anodes, ${ }^{19-22}$ suggests that the unexpectedly 
low barrier for hole conduction through the amorphous $\mathrm{TiO}_{2}$ layer involves hole-tunnelling through an

187 ultrathin $(<2 \mathrm{~nm}) \mathrm{SiO}_{2}$ interface layer and then a polaronic or hopping conduction mechanism through the $\mathrm{TiO}_{2}$ protective layer to the Ir catalyst film. Importantly, in the absence of light, the current is negligible, i.e. $<1 \mu \mathrm{A} \mathrm{cm}{ }^{-2}$, at the potentials used in Figure 4, due to the very low thermal population of holes in the $\mathrm{n}-\mathrm{Si}$. Thus, in the dark the $\mathrm{n}-\mathrm{Si} / \mathrm{TiO}_{2} / \mathrm{Ir}$ photoanode is not able to effect either the water oxidation or chloride oxidation half-cell reactions, but is able to do so upon illumination with ultra-band gap light, as illustrated by the photoelectrochemical data in Figure 4.

LSV's: Tafel slopes, overpotentials and photovoltages

194

Linear sweep voltammograms, LSVs, for water oxidation, i.e. reaction (2), were recorded for the n$\mathrm{Si} / \mathrm{TiO}_{2} / \mathrm{Ir}$ photoanode, under 1 sun illumination, and the $\mathrm{p}+-\mathrm{Si} / \mathrm{TiO}_{2} / \mathrm{Ir}$ anode (in the dark) in $0.5 \mathrm{M}$ $\mathrm{H}_{2} \mathrm{SO}_{4}$ and the results are illustrated in Figure 5(a). Similarly, LSVs for chloride oxidation, i.e. reaction (1), were recorded for the $\mathrm{n}-\mathrm{Si} / \mathrm{TiO}_{2} / \mathrm{Ir}$ photoanode - under 1 sun illumination, and the $\mathrm{p}+-$ $\mathrm{Si} / \mathrm{TiO}_{2} / \mathrm{Ir}$ anode (in the dark) in a $\left(0.5 \mathrm{M} \mathrm{H}_{2} \mathrm{SO}_{4}\right.$ plus $\left.3.5 \mathrm{M} \mathrm{NaCl}\right)$ electrolyte and the results are illustrated in Figure 5(b). The broken vertical lines highlight the formal redox potentials, $E^{o 1}$, of the $\mathrm{O}_{2} / \mathrm{H}_{2} \mathrm{O}$ (black) and $\mathrm{Cl}^{-} / \mathrm{Cl}_{2}$ (red) couples in $0.5 \mathrm{M} \mathrm{H}_{2} \mathrm{SO}_{4}$ and $\left(0.5 \mathrm{M} \mathrm{H}_{2} \mathrm{SO}_{4}\right.$ plus $\left.3.5 \mathrm{M} \mathrm{NaCl}\right)$ electrolytes, respectively, calculated, using the Nernst equation, to be: 1.212 and $1.328 \mathrm{~V}$, respectively.

The data associated with each of the LSV's illustrated in Figure 5 provides a good fit to the Tafel equation, i.e. ${ }^{23}$

$$
\eta=a+b \cdot \log (i)
$$

where, $\eta=$ overpotential (= applied bias, $\mathrm{V}_{\mathrm{b}},-\mathrm{E}^{\mathrm{o}^{\prime}}$ ), $a$ and $b$ are constants (units: $\mathrm{V}$ ) and $i$ is the current density (units: $\mathrm{mA} \mathrm{cm}^{-2}$ ). It follows from eqn (4) that the value of the constant ' $a$ ' is the overpotential necessary to generate a current/photocurrent density of $1 \mathrm{~mA} \mathrm{~cm}{ }^{-2}$ and ' $b$ ' is the Tafel slope, which can provide an insight into the mechanism that underpins the associated electrochemical oxidation. A summary of the $a$ and $b$ terms determined by this analysis for the two electrodes in the two different electrolytic solutions, derived from Tafel plots of the data in Figure 5, is given in Table 1. The ' $a$ ' 
212 values in parenthesis for water oxidation are those reported by Chen et al. ${ }^{13}$ for similar electrodes, 213 although with a thicker Ir layer, i.e. $3 \mathrm{~nm}$ rather than the $2 \mathrm{~nm}$ used here, and in $1 \mathrm{M} \mathrm{H}_{2} \mathrm{SO}_{4}$.

214 Reassuringly both studies report a very similar photovoltage, i.e. $0.568 \mathrm{~V}$ compared with the value of $0.532 \mathrm{~V}$ reported by Chen et al. ${ }^{13}$. As noted by these workers, this photovoltage is similar to that of the best Si photoelectrochemical solar cells. ${ }^{24}$

Table 1 shows the Tafel slope to be between $70-80 \mathrm{mV} / \mathrm{decade}$, with previous works reporting Tafel slopes in the range of $34-54 \mathrm{mV} / \mathrm{decade}^{5,25,26}$ for iridium oxide catalysts. Slopes around $40 \mathrm{mV} / \mathrm{decade}$ are commonly attributed to a Heyrovsky-type rate limiting step, ${ }^{27}$ and are associated with electrochemical desorption being slow. ${ }^{5}$ It is worth noting that these previous works study iridium oxide materials, synthesized either by electrochemical cycling or thermal decomposition ${ }^{25}$. This work employs an iridium metal catalyst that may not fully oxidize during operation, which may result in different Tafel slopes for those more reduced regions. This is in agreement with Tilak's work, which subjected iridium anodes to cathodic current prior to testing and saw higher Tafel slopes (46$54 \mathrm{mV} /$ decade) for a more reduced iridium catalyst. ${ }^{5}$ Despite these slightly sub-optimal Tafel slopes, these $\mathrm{ALD}-\mathrm{TiO}_{2}$ protection layers have been shown to support a wide variety of catalyst materials for the water oxidation reaction ${ }^{19,28}$, implying the protection layer is robust enough to support further optimization of the catalyst layer.

\section{$\mathrm{Cl}_{2}$ yield and stability}

As note earlier, examination of either the CV data in Figure 4, or the LSV data in Figure 5, reveals a significant separation (i.e. ca. $0.290 \mathrm{~V}$ from data in Table 1) between the two photocurrent LSV plots for the $\mathrm{n}-\mathrm{Si} / \mathrm{TiO}_{2} / \mathrm{Ir}$, under 1 sun illumination, in the two different electrolytes, $0.5 \mathrm{M} \mathrm{H}_{2} \mathrm{SO}_{4}$ and $(0.5$ $\mathrm{M} \mathrm{H}_{2} \mathrm{SO}_{4}+3.5 \mathrm{M} \mathrm{NaCl}$ ), respectively. A similar separation is found for the $\mathrm{p}+-\mathrm{Si} / \mathrm{TiO}_{2} / \mathrm{Ir}$ anode (i.e. $0.294 \mathrm{~V}$ from data in Table 1). This feature suggests that when operated at a modest photocurrent, or current, (i.e. 1-2 mA) the n-Si/ $\mathrm{TiO}_{2} / \mathrm{Ir}$ photoanode, or $\mathrm{p}+-\mathrm{Si} / \mathrm{TiO}_{2} / \mathrm{Ir}$ anode, should, almost exclusively, mediate the oxidation of chloride, reaction (1), rather than that of water, reaction (2), so that the yield 
of chlorine should be very high. In order to test this prediction, the $\mathrm{Si} / \mathrm{TiO}_{2} / \mathrm{Ir}$ photoanode (under 1 sun irradiation, polarized at $0.72 \mathrm{~V} \mathrm{vs} \mathrm{Ag} / \mathrm{AgCl}$ ) and the $\mathrm{p}+-\mathrm{Si} / \mathrm{TiO} / 2 \mathrm{Ir}$ anode (in dark, polarized at $1.18 \mathrm{~V}$ vs $\mathrm{Ag} / \mathrm{AgCl}$ ) were operated in chronoamperometric mode for 1 hour, during which not only was the current monitored but also any chlorine generated in the electrochemical cell was swept, by a continual stream of Ar, from the electrolyte to an aqueous trap solution $\left(100 \mathrm{~cm}^{3}\right)$, comprising a mixture of $\mathrm{KI}(0.36 \mathrm{M}), \mathrm{NaOH}(0.025 \mathrm{M})$ and potassium hydrogen phthalate $(0.049 \mathrm{M})^{29}$. Previous work has demonstrated that the latter solution acts as a very efficient trap for chlorine in a stream of an inert gas, but not for oxygen. In the trap the $\mathrm{Cl}_{2}$ reacts with the iodide in the trap solution to form tri-iodide, the concentration of which can then be assessed spectrophotometrically, given the molar absorptivity $\varepsilon\left(\mathrm{I}_{3}^{-}\right)=26400 \mathrm{~L} \mathrm{~cm}^{-1} \mathrm{~mol}^{-1}$ at $353 \mathrm{~nm} \cdot{ }^{14}$

Figure 6 illustrates the chronoamperograms recorded for the $\mathrm{Si} / \mathrm{TiO}_{2} / \mathrm{Ir}$ photoanode and the $\mathrm{p}+-$ $\mathrm{Si} / \mathrm{TiO}_{2} / \mathrm{Ir}$ anode in an electrolyte of $\left(0.5 \mathrm{M} \mathrm{H}_{2} \mathrm{SO}_{4}+3.5 \mathrm{M} \mathrm{NaCl}\right)$. The initial drift downwards in current does not appear to be due to the loss of electrocatalyst as the same feature was observed in a repeat experiment using the same, used, electrodes and was also observed when an Ir rod was used as the anode. Instead, it appears to be due to gas bubble formation on the surface of the electrodes. From the ratio of the total amount of triodide trapped $\left(3.13 \times 10^{-6}\right.$ moles for the $\mathrm{n}-\mathrm{Si} / \mathrm{TiO}_{2} / \mathrm{Ir}$ photoanode) to the total amount of charge passed $\left(\mathrm{Q}=0.71 \mathrm{C}\right.$ for the $\mathrm{n}-\mathrm{Si} / \mathrm{TiO}_{2} / \mathrm{Ir}$ photoanode $)$ Faradaic efficiencies for $\mathrm{Cl}_{2}$ production were determined to be $85 \%$ and $92 \%$ for the $\mathrm{nSi} / \mathrm{TiO}_{2} / \mathrm{Ir}$ photoanode and the $\mathrm{p}+-\mathrm{Si} / \mathrm{TiO}_{2} / \mathrm{Ir}$ anode, respectively. Similar yields were determined using an $\mathrm{Ir}$ rod as the anode and also a dimensionally stable anode, comprising a film of $\mathrm{RuO}_{2} / \mathrm{TiO}_{2}$ on a $\mathrm{Ti}$ foil ${ }^{30}$, and the slightly less than $100 \%$ Faradaic efficiencies for $\mathrm{Cl}_{2}$ production for all these electrodes was attributed to a small degree of reaction of the very aggressively oxidising chlorine with the components of the system as it was swept from the electrochemical cell to the trap solution.

Chlorine is a very reactive oxidising agent, thus any protective coating has to be sufficiently robust chemically to withstand the highly corrosive action of chlorine in a highly acidic environment. Without this $\mathrm{TiO}_{2}$ coating, even with an Ir catalyst layer, none of the $\mathrm{p}^{+-\mathrm{Si}}$ and $\mathrm{n}-\mathrm{Si}$ anodes are stable and able to effect the oxidation of either water or chloride. In order to probe the stability of the $\mathrm{TiO}_{2}$ 
protective coating and the overall photostability of the photonaode, a chronopotentiogram was recorded, with the current set at $1 \mathrm{~mA} \mathrm{~cm}^{-2}$, for the $\mathrm{Si} / \mathrm{TiO}_{2} / \mathrm{Ir}$ photoanode (irradiated with a UV 455 $\mathrm{nm}$ LED; $6.5 \mathrm{~mW} \mathrm{~cm}^{-2}$ ) over a period of $\mathrm{ca} 6$ days and the results are illustrated in Figure 7.

The short disruption in the current -time plot at $3 \mathrm{~d}$, see Figure 7, was due to $\mathrm{Cl}_{2}$ bubble formation, which - once cleared - allowed the photoelectrode to function as before. The $\% \mathrm{Cl}_{2}$ yield was measured for the first and last hour of this run and found to be in both cases ca. $85 \%$ as in Figure 6 . The results illustrated in Figure 7 indicate that the $\mathrm{n}-\mathrm{Si} / \mathrm{TiO}_{2} / \mathrm{Ir}$ photoanode is stable over a 6 -day period when used to photo-electrochemically oxidized chloride to chlorine under acidic conditions.

Films as-deposited are conformal, metallic iridium films, and remain unbroken after stability testing. X-ray Photoelectron Spectroscopy confirms the iridium oxidizes during stability measurements, but retains both oxide and metallic components. (see Figures S2-4) Scanning Auger Electron Microscopy confirms the iridium film remains intact, with only slight carbon contamination. (Figure S4)

\section{Efficiency}

Finally, the n-Si/ $/ \mathrm{TiO}_{2} / \mathrm{Ir}$ photoanode was used in a 2-electrode format, using a wound $\mathrm{Pt}$ wire (surface area $=2.5 \mathrm{~cm}^{2}$ ) as the counter electrode and the photocurrents, $i$, measured under 1 sun illumination as a function of applied bias, $\mathrm{V}_{\mathrm{b}}$ (in volts), in the following electrolytes: $0.5 \mathrm{M} \mathrm{H}_{2} \mathrm{SO}_{4}$ (water oxidation) and $\left(0.5 \mathrm{M} \mathrm{H}_{2} \mathrm{SO}_{4}\right.$ plus $\left.3.5 \mathrm{M} \mathrm{NaCl}\right)$ (chloride oxidation). These data were then used to calculate the applied bias photon-to-current efficiency (ABPE) for the photocleavage of water and the photoelectrolysis of the acidified brine by the $\mathrm{n}-\mathrm{Si} / \mathrm{TiO}_{2} / \mathrm{Ir}$ photoanode under 1 sun illumination, based on the following expression:

$$
\mathrm{ABPE}=i\left(\mathrm{~mA} \mathrm{~cm}^{-2}\right) \mathrm{x}\left(\mathrm{E}_{\text {ref }}-\mathrm{V}_{\mathrm{b}}\right) / \mathrm{P}_{\text {total }}\left(\mathrm{mW} \mathrm{cm}^{-2}\right)
$$

where, $\mathrm{E}_{\text {ref }}=1.212 \mathrm{~V}$ in $0.5 \mathrm{M} \mathrm{H}_{2} \mathrm{SO}_{4}$ (for water oxidation) and $1.328 \mathrm{~V}$ in $\left(0.5 \mathrm{M} \mathrm{H}_{2} \mathrm{SO}_{4}\right.$ plus $3.5 \mathrm{M}$ $\mathrm{NaCl}$ ) (for chloride oxidation) and $\mathrm{P}_{\text {total }}=$ incident illumination power density $=100 \mathrm{~mW} \mathrm{~cm}$; note: this equation assumes $100 \%$ Faradaic efficiency in the production of $\mathrm{O}_{2}$ or $\mathrm{Cl}_{2}$. 
The plots of ABPE vs $\mathrm{V}_{\mathrm{b}}$ are illustrated in Figure 8 and reveal maximum values for water splitting and acidified brine photoelectrolysis of $0.05 \%$ and $1.42 \%$, respectively. The 28 times increase in efficiency for the photo-oxidation of the brine, compared to that of water in acid solution is primarily due to the fact that the overpotential for the former reaction is much lower than that for the latter, see Table 1, so that a greater fraction of the photovoltage, ca. $560 \mathrm{mV}$ is utilized for fuel $\left(\mathrm{H}_{2}\right)$ and disinfectant $\left(\mathrm{Cl}_{2}\right)$ production. The ABPE value of $1.42 \%$ compares very well with that of $0.6 \%$ reported by Kim et al. ${ }^{31}$ for their record-breaking single crystal, worm-like hematite photoanodes for water oxidation, although, in the latter case, the value of $0.6 \%$ is flattered by the use of a 3 -electrode cell, which excludes any loss in efficiency due to the counter electrode reaction, as is found for many reported $\mathrm{ABPE}$ and Solar to Hydrogen Efficiency (STH) values. ${ }^{32}$ As noted earlier, ultimately the photoanode will be paired with an appropriate photocathode in a tandem cell, or be made part of a photovoltaic triple junction, which will reduce significantly the value for $\mathrm{V}_{\mathrm{b}}$ and so improve markedly the value of ABPE. However, as it stands this is the first use of a low bandgap semiconductor photoanode to photoelectrolyze (acidified) brine so as to generate a fuel $\left(\mathrm{H}_{2}\right)$ and a disinfectant $\left(\mathrm{Cl}_{2}\right)$ with an efficiency superior to that of leading reported photoanodes used to photodissociate water. ${ }^{31}$

\section{Conclusion}

An n-type silicon photoanode, utilizing a $2 \mathrm{~nm}$ thin film iridium catalyst protected by a $1.7 \mathrm{~nm}$ thickness coating of atomic layer deposited amorphous $\mathrm{TiO}_{2}$, is able to effect the photo-oxidation of water to $\mathrm{O}_{2}$ and of chloride to $\mathrm{Cl}_{2}$, with an incident photon-to-current efficiency that increases with increasing bias voltage, eventually reaching ca. $100 \%$ efficiency if light loss due to Ir film absorption is taken into consideration. In $0.5 \mathrm{M} \mathrm{H}_{2} \mathrm{SO}_{4}$ acid, the photo-oxidation of water occurs at potentials that are ca. $290 \mathrm{mV}$ greater than that for chloride oxidation $\left(0.5 \mathrm{M} \mathrm{H}_{2} \mathrm{SO}_{4}\right.$ plus $\left.3.5 \mathrm{M} \mathrm{NaCl}\right)$, which allows the $n-\mathrm{Si} / \mathrm{TiO}_{2} / \mathrm{Ir}$ photoanode (1 sun illumination) and dark $\mathrm{p}+-\mathrm{Si} / \mathrm{TiO}_{2} / \mathrm{Ir}$ anode to generate $\mathrm{Cl}_{2}$ with a high ( $>85 \%$ ) yield. Applied bias photon-to-current efficiencies of $0.05 \%$ and $1.42 \%$ were determined for the $\mathrm{n}-\mathrm{Si} / \mathrm{TiO}_{2} / \mathrm{Ir}$ photoanode for water and chloride oxidation respectively. The latter value is particularly encouraging, especially given the potential for improvement when the n$\mathrm{Si} / \mathrm{TiO}_{2} / \mathrm{Ir}$ photoanode is coupled to an appropriate photocathode in a tandem cell, or used in a triple 
317 junction photovoltaic. This initial study illustrates the effectiveness of layered $\mathrm{ALD}^{-\mathrm{TiO}_{2}}$ and $\mathrm{Ir}$ thin

318 film coatings in simultaneously protecting silicon photoanodes from corrosion and achieving low 319 overpotentials and large photovoltages to generate both a fuel but a disinfectant and a water 320 disinfectant in a photoelectrochemical device.

321 


\section{References}

323 1. Lewis, N. S. \& Nocera, D. G. Powering the planet: Chemical challenges in solar energy utilization. Proc. Natl. Acad. Sci. 103, 15729-15735 (2006).

2. Walter, M. G. et al. Solar Water Splitting Cells. Chem. Rev. (Washington, DC, United States) 110, 6446-6473 (2010). $<$ https://www.scientificamerican.com/article/energy-from-a-water-bottle/>

4. Reece, S. Y. et al. Wireless Solar Water Splitting Using Silicon-Based Semeiconductors and Earth-Abundant Catalysts. Science (80-. ). 334, 645-648 (2011).

9. Hu, S. et al. Thin-Film Materials for the Protection of Semiconducting Photoelectrodes in Solar-Fuels Generators. J. Phys. Chem. C 150928141004000 (2015). doi:10.1021/acs.jpcc.5b05976

10. Aromaa, J. \& Forsén, O. Evaluation of the electrochemical activity of a Ti-RuO2-TiO2 permanent anode. Electrochim. Acta 51, 6104-6110 (2006).

11. Morita, M., Iwakura, C. \& Tamura, H. The anodic characteristics of modified Mn oxide electrode: Ti/RuOx/MnOx. Electrochim. Acta 23, 331-335 (1978).

12. Duby, P. The history of progress in dimensionally stable anodes. JOM 45, 41-43 
13. Chen, Y. W. et al. Atomic layer-deposited tunnel oxide stabilizes silicon photoanodes for water oxidation. Nat. Mater. 10, 539-544 (2011).

14. Mills, A. \& Cook, A. Analysis of chlorine - oxygen gas mixtures. Analyst 112, 12891291 (1987).

15. Meng, H., Fan, K., Low, J. \& Yu, J. Electrochemically reduced graphene oxide on silicon nanowire arrays for enhanced photoelectrochemical hydrogen evolution. Dalt. Trans. 45, 13717-13725 (2016).

16. Hu, S. et al. Amorphous $\mathrm{TiO} 2$ coatings stabilize $\mathrm{Si}, \mathrm{GaAs}$, and $\mathrm{GaP}$ photoanodes for efficient water oxidation. Science 344, 1005-9 (2014).

17. Bae, D. et al. Back-Illuminated Si-Based Photoanode with Nickel Cobalt Oxide Catalytic Protection Layer. ChemElectroChem 3, 1517 (2016).

18. Li, C. et al. Efficient photoelectrochemical water oxidation enabled by an amorphous metal oxide-catalyzed graphene/silicon heterojunction photoanode. Sustain. Energy Fuels 663-672 (2018). doi:10.1039/C7SE00504K

19. Scheuermann, A. G., Prange, J. D., Gunji, M., Chidsey, C. E. D. \& McIntyre, P. C. Effects of catalyst material and atomic layer deposited TiO2 oxide thickness on the water oxidation pe rformance of metal-insulator-silicon anodes. Energy Environ. Sci. 6, $2487(2013)$.

20. Campet, G., Manaud, J. P., Puprichitkun, C., Sun, Z. W. \& Salvador, P. Protection of photoanodes against photo-corrosion by surface deposition of oxide films: criteria for choosing the protective coating. Act. Passiv. Electron. Components 13, 175-189 (1989).

21. Batzill, M., Katsiev, K., Gaspar, D. J. \& Diebold, U. Variations of the local electronic surface properties of TiO2 (110) induced by intrinsic and extrinsic defects. Phys. Rev. 
B 66, 235401 (2002).

373

374

375

376

377

378

379

380

381

382

383

384

385

386

387

388

389

390

391

392

393

394

395

396

22. Papageorgiou, A. C. et al. Electron traps and their effect on the surface chemistry of TiO2(110). Proc. Natl. Acad. Sci. 107, 2391-2396 (2010).

23. Bagotsky, V. S. Fundamentals of Electrochemistry. (Wiley-Interscience, 2006).

24. Switzer, J. A. The n-Silicon/Thallium(III) Oxide Heterojunction Photoelectrochemical Solar Cell. J. Electrochem. Soc. 133, 722 (1986).

25. Consonni, V., Trasatti, S., Pollak, F. \& O’Grady, W. E. Mechanism of chlorine evolution on oxide anodes study of pH effects. J. Electroanal. Chem. 228, 393-406 (1987).

26. Mozota, J. Modification of Apparent Electrocatalysis for Anodic Chlorine Evolution on Electrochemically Conditioned Oxide Films at Iridium Anodes. J. Electrochem. Soc. 128, 2142 (1981).

27. Shinagawa, T., Garcia-Esparza, A. T. \& Takanabe, K. Insight on Tafel slopes from a microkinetic analysis of aqueous electrocatalysis for energy conversion. Sci. Rep. 5, 1$21(2015)$

28. McDowell, M. T. et al. The Influence of Structure and Processing on the Behavior of TiO 2 Protective Layers for Stabilization of n-Si/TiO 2 /Ni Photoanodes for Water Oxidation. ACS Appl. Mater. Interfaces (2015). doi:10.1021/acsami.5b00379

29. Hernández-Pagán, E. A. et al. Resistance and polarization losses in aqueous buffermembrane electrolytes for water-splitting photoelectrochemical cells. Energy Environ. Sci. 5, 7582-7589 (2012).

30. O'Brien, T. F., Bommaraju, T. V \& Hine, F. in Handbook of Chlor-Alkali Technology: Volume I: Fundamentals (Springer USA, 2005). doi:10.1007/0-306-48624-5_5

31. Kim, J. Y. et al. Single-crystalline, wormlike hematite photoanodes for efficient solar water splitting. Sci. Rep. 3, 1-8 (2013). 
32. Chen, Z., Dinh, H. \& Miller, E. Photoelectrochemical Water Splitting: Standards,

399

400 


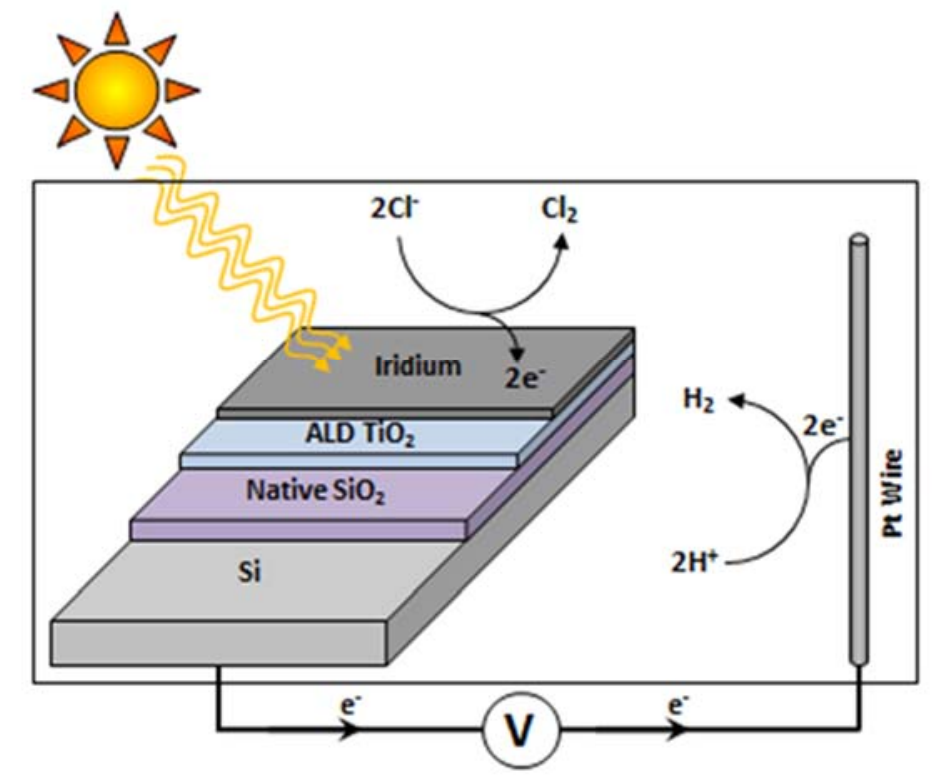

401

402 Figure 1: Schematic illustration of the $\mathrm{n}-\mathrm{Si} / \mathrm{TiO}_{2} / \mathrm{Ir}$ photoanode used to photo-oxidize chloride $(3.5 \mathrm{M}$ $403 \mathrm{NaCl})$ to chlorine in acid $\left(0.5 \mathrm{M} \mathrm{H}_{2} \mathrm{SO}_{4}\right)$

404 


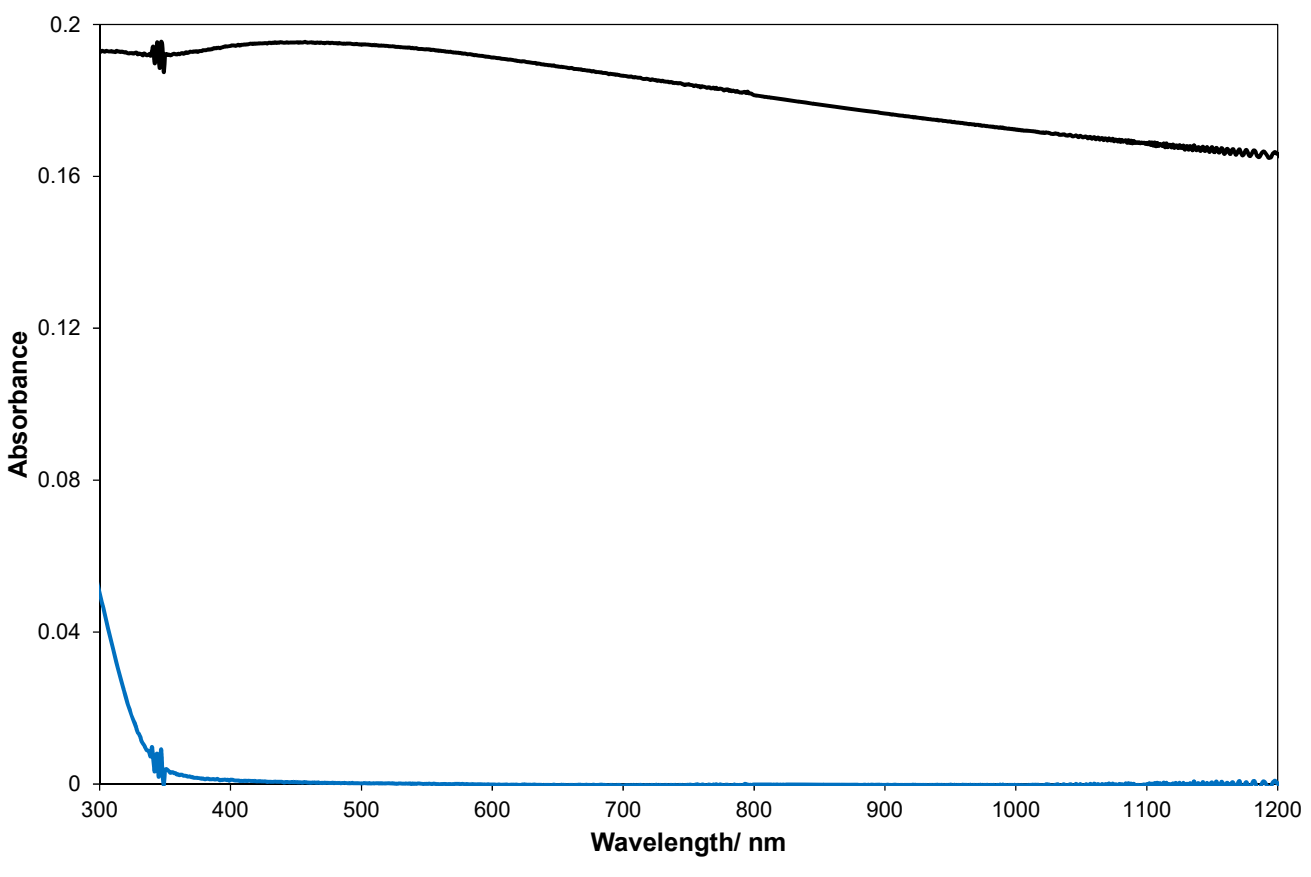

405

406 Figure 2: UV/Vis/NIR spectra of the following films on quartz: (i) $2 \mathrm{~nm}$ of evaporated Ir (black line) 407 and (ii) $1.7 \mathrm{~nm}$ of ALD-deposited amorphous $\mathrm{TiO}_{2}$ (blue line).

408 


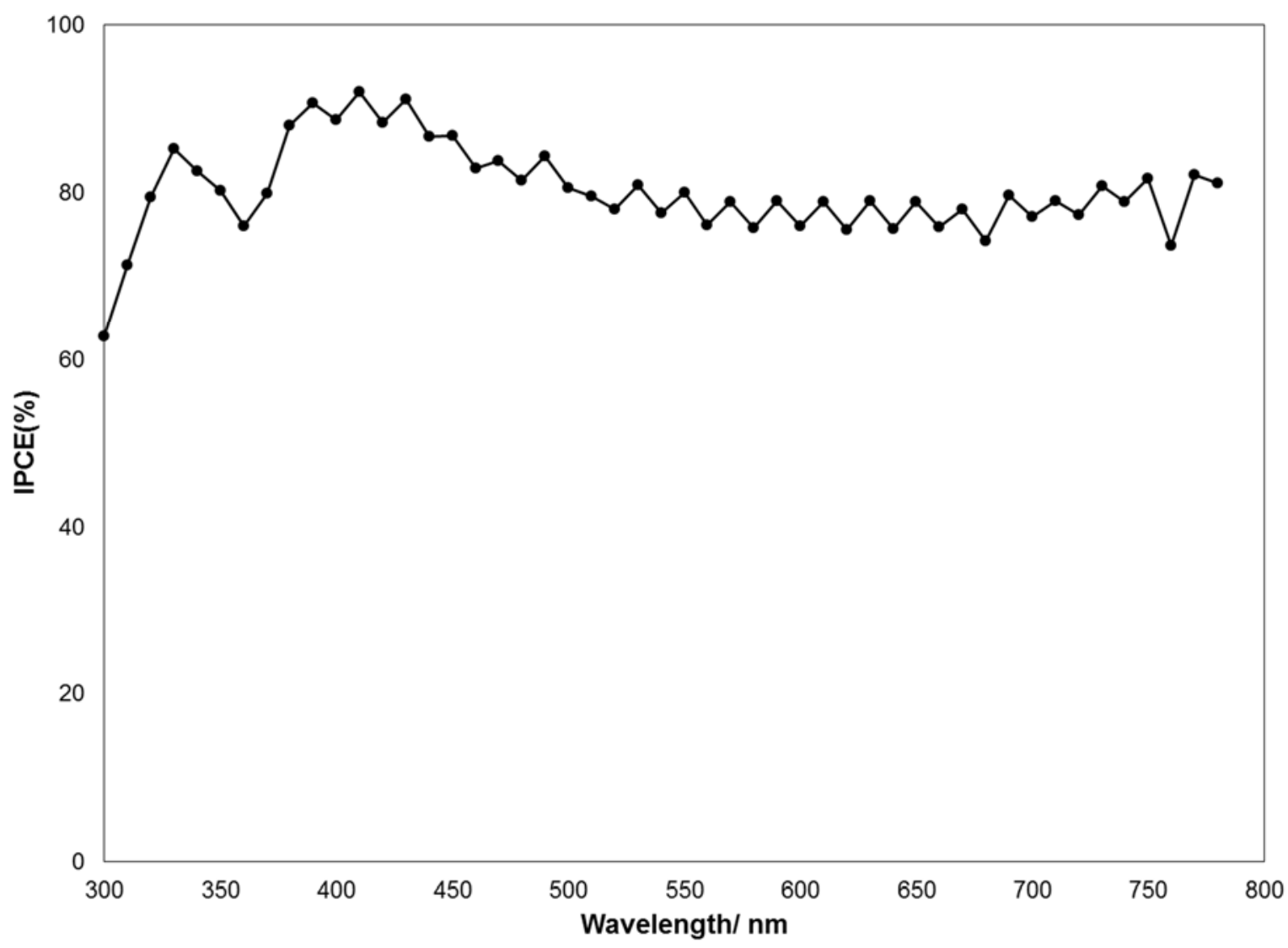

409

410 Figure 3: IPCE spectrum of the $\mathrm{n}-\mathrm{Si} / 2 \mathrm{~nm} \mathrm{TiO}_{2} / 2 \mathrm{~nm} \mathrm{Ir}$ anode at $1.8 \mathrm{~V}$ vs NHE and a $0.8 \mathrm{~cm}^{2}$ active 411 area. Electrolyte was $0.5 \mathrm{M} \mathrm{H}_{2} \mathrm{SO}_{4}+3.5 \mathrm{M} \mathrm{NaCl}$.

412 


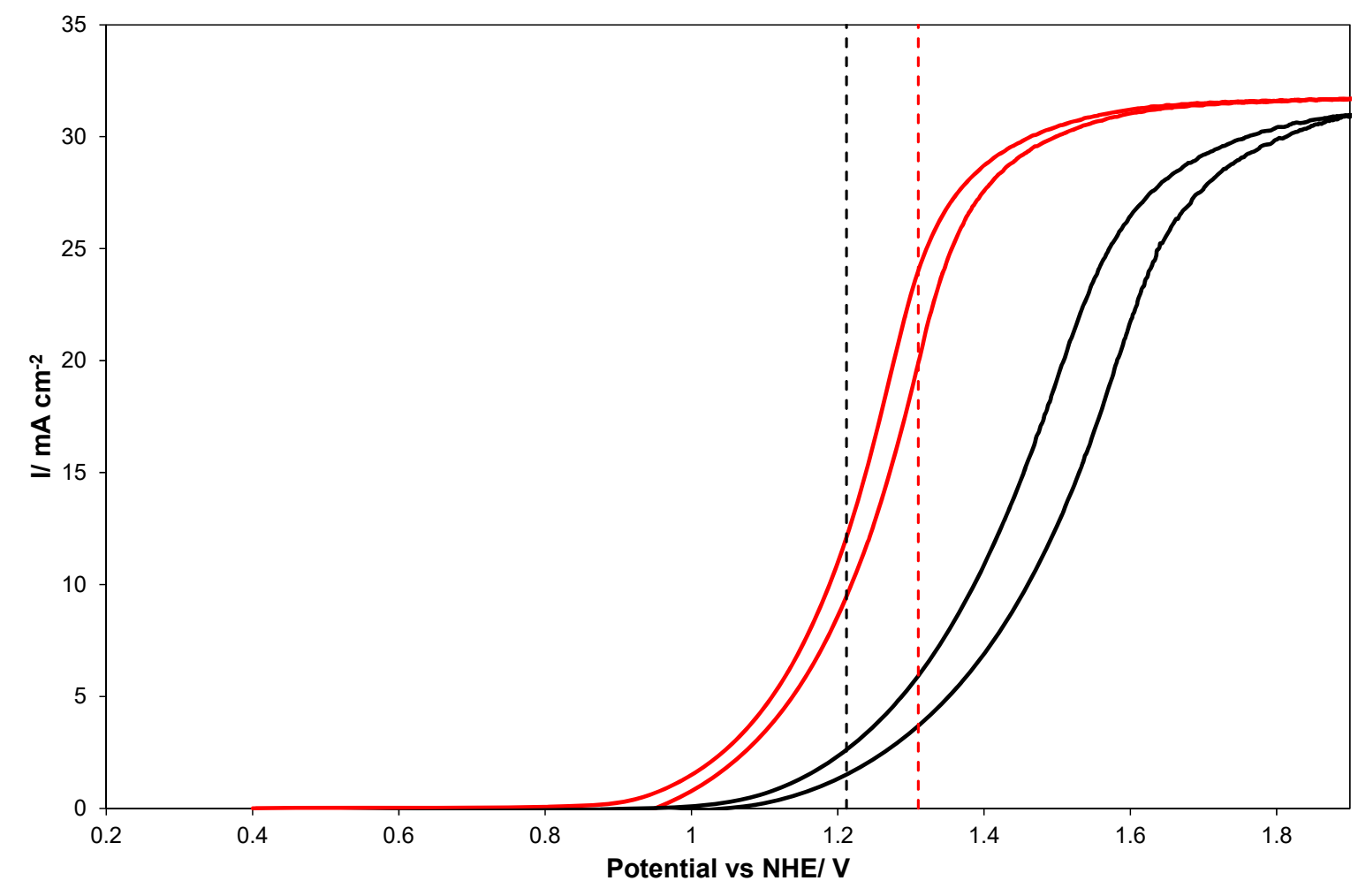

413

414 Figure 4: $\mathrm{CVs}$ for the $\mathrm{n}-\mathrm{Si} / \mathrm{TiO}_{2} / \mathrm{Ir}$ photoanode under 1 sun irradiation, sweep rate: $100 \mathrm{mV} \mathrm{s}^{-1}$ 415 recorded in $0.5 \mathrm{M} \mathrm{H}_{2} \mathrm{SO}_{4}$ (black line) or $0.5 \mathrm{M} \mathrm{H}_{2} \mathrm{SO}_{4}$ plus $3.5 \mathrm{M} \mathrm{NaCl}$ (red line) under 1 sun 416 irradiation, i.e. $100 \mathrm{~mW} \mathrm{~cm}$. The broken vertical lines represent the thermodynamic potentials for 417 reaction (1) (broken red line) ad reaction (2) (broken black line). 

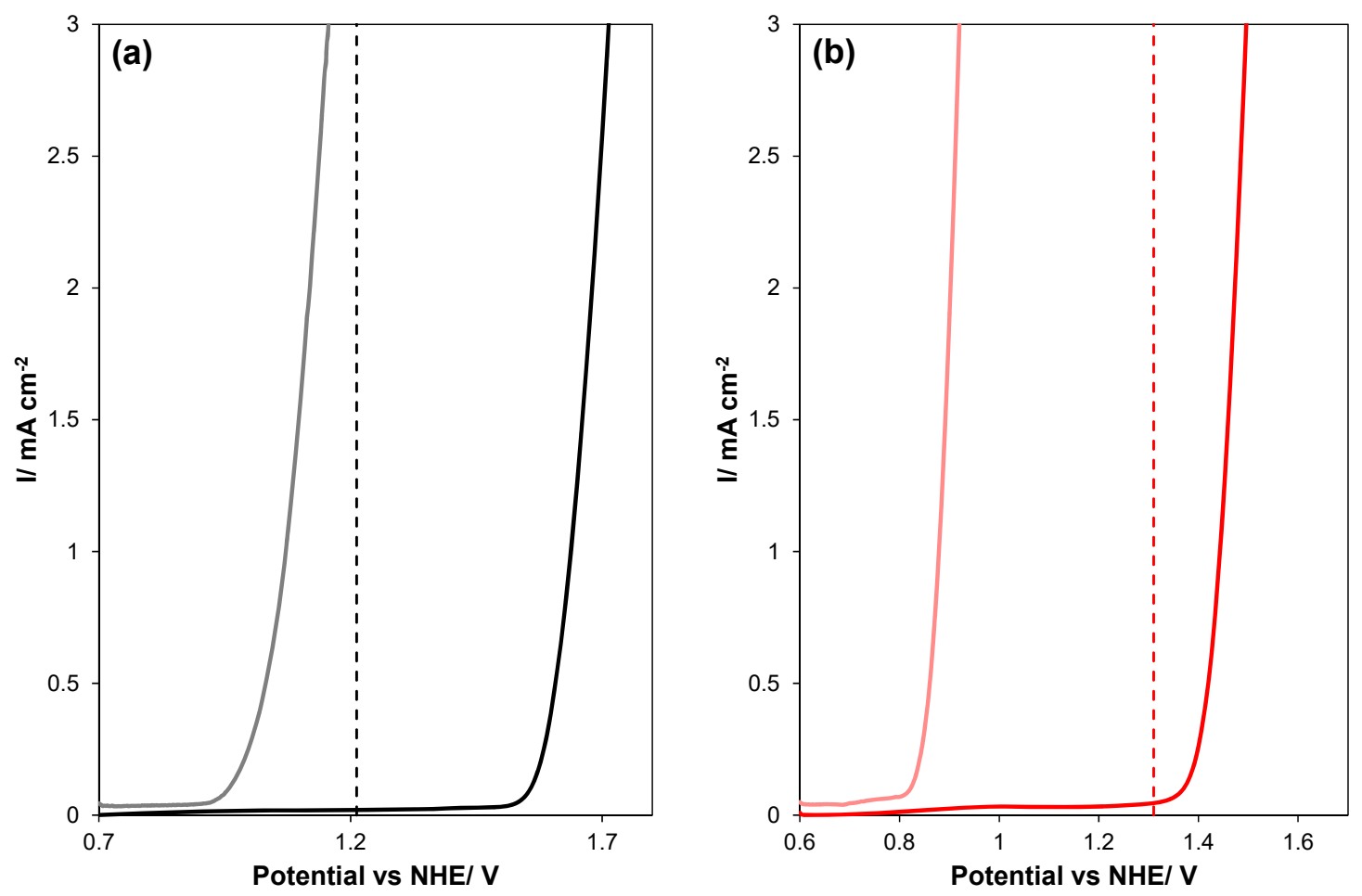

418

419 Figure 5: LSV curves for (from left to right): a $\mathrm{p}+-\mathrm{Si} / \mathrm{TiO}_{2} / \mathrm{Ir}$ anode (in the dark) and an n-Si/ $/ \mathrm{TiO}_{2} / \mathrm{Ir}$, 420 under 1 sun irradiation, in (a) $0.5 \mathrm{M} \mathrm{H}_{2} \mathrm{SO}_{4}$ (black lines) and (b) $\left(0.5 \mathrm{M} \mathrm{H}_{2} \mathrm{SO}_{4}+3.5 \mathrm{M} \mathrm{NaCl}\right)$, (red 421 lines) respectively. The broken vertical lines in (a) and (b) represent the thermodynamic potentials for 422 reaction (1) (red line) and reaction (2) (black line), respectively. 
423 Table 1: Results of Tafel plot analysis of $\mathrm{LSVs}_{\text {for }}$ the $\mathrm{Si} / \mathrm{TiO}_{2} / \mathrm{Ir}$ photoanode and $\mathrm{p}+-\mathrm{Si} / \mathrm{TiO}_{2} / \mathrm{Ir}$ 424 anode

\begin{tabular}{|c|c|c|c|}
\hline Anode & $a / \mathbf{V}$ & $b / \mathbf{V}$ & $\mathbf{V}_{\text {photo }} \dagger / \mathbf{V}$ \\
\hline \multicolumn{4}{|c|}{ Water oxidation (0.5 $\left.\mathrm{M} \mathrm{H}_{2} \mathrm{SO}_{4}\right)$} \\
\hline $\mathrm{p}+-\mathrm{Si} / \mathrm{TiO}_{2} / \mathrm{Ir}$ & $0.428(0.332) \$$ & 0.122 & \multirow[t]{2}{*}{$0.568(0.532)$} \\
\hline $\mathrm{n}-\mathrm{Si} / \mathrm{TiO}_{2} / \mathrm{Ir} *$ & $-0.140(-0.200)$ & 0.144 & \\
\hline \multicolumn{4}{|c|}{ Chloride oxidation ( $\left.0.5 \mathrm{M} \mathrm{H}_{2} \mathrm{SO}_{4}+3.5 \mathrm{M} \mathrm{NaCl}\right)$} \\
\hline $\mathrm{p}+-\mathrm{Si} / \mathrm{TiO}_{2} / \mathrm{Ir}$ & 0.134 & 0.089 & \multirow[t]{2}{*}{0.564} \\
\hline $\mathrm{n}-\mathrm{Si} / \mathrm{TiO}_{2} / \mathrm{Ir}^{*}$ & -0.430 & 0.069 & \\
\hline
\end{tabular}

$425 * 1$ sun irradiation; $1100 \mathrm{~mW} \mathrm{~cm}^{-2}$

$426 \uparrow: \mathrm{V}_{\text {photo }}=$ photovoltage $=a\left(\mathrm{n}-\mathrm{Si} / \mathrm{TiO}_{2} / \mathrm{Ir}^{*}\right)-a\left(\mathrm{p}+-\mathrm{Si} / \mathrm{TiO}_{2} / \mathrm{Ir}\right)$

$427 \quad$ : Values reported by Chen et al in $1 \mathrm{M} \mathrm{H}_{2} \mathrm{SO}_{4}$ 


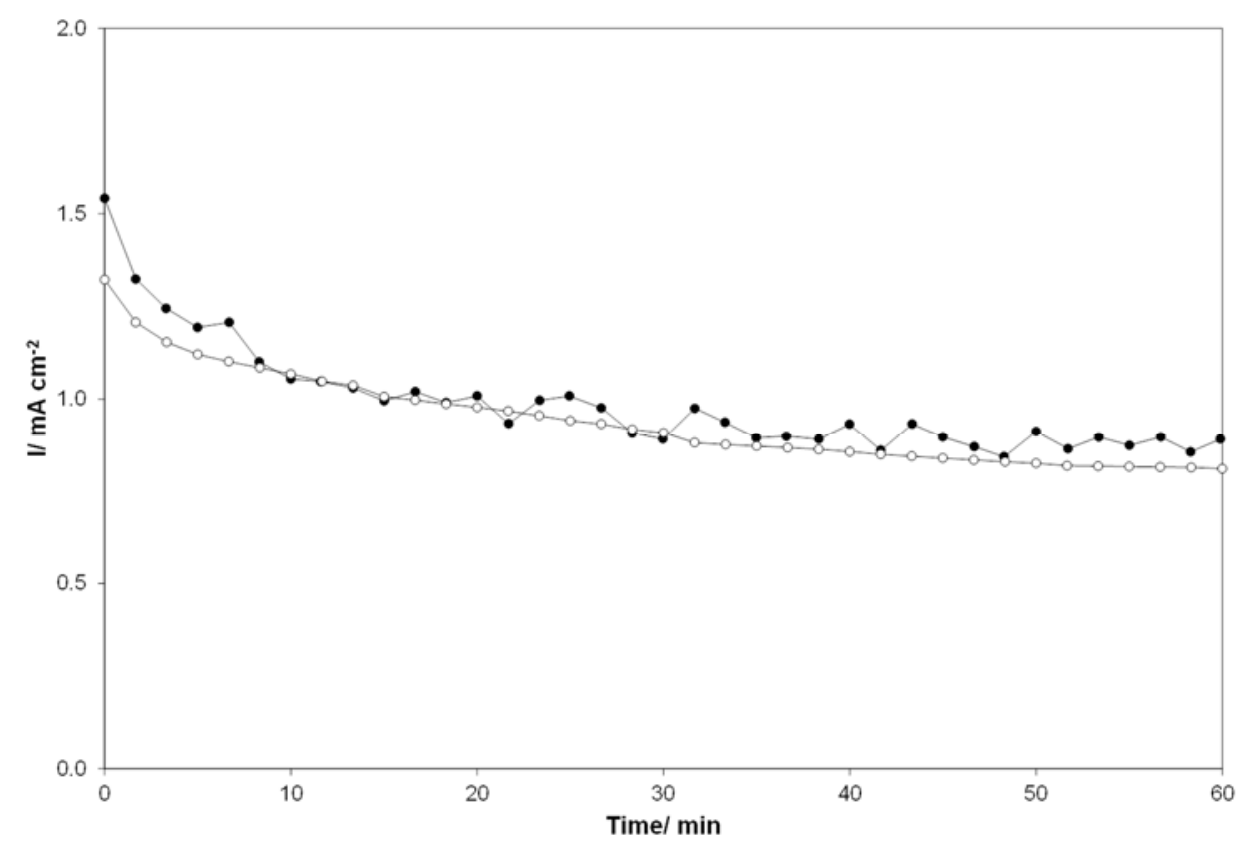

429 Figure 6: Chronoamperograms recorded using the electrochemical cell illustrated in figure S1 and 430 either: (i) a $\mathrm{Si} / \mathrm{TiO}_{2} / \mathrm{Ir}$ photoanode, - , (under 1 sun irradiation, polarized at $0.72 \mathrm{~V}$ vs $\mathrm{Ag} / \mathrm{AgCl}$ ), or 431 (ii) a $\mathrm{p}^{+-}-\mathrm{Si} / \mathrm{TiO}_{2} / \mathrm{Ir}$ anode, $\bigcirc$ (in dark, polarized at $1.18 \mathrm{~V}$ vs $\left.\mathrm{Ag} / \mathrm{AgCl}\right)$ using a electrolyte of: $(0.5 \mathrm{M}$ $\left.432 \mathrm{H}_{2} \mathrm{SO}_{4}+3.5 \mathrm{M} \mathrm{NaCl}\right)$. 


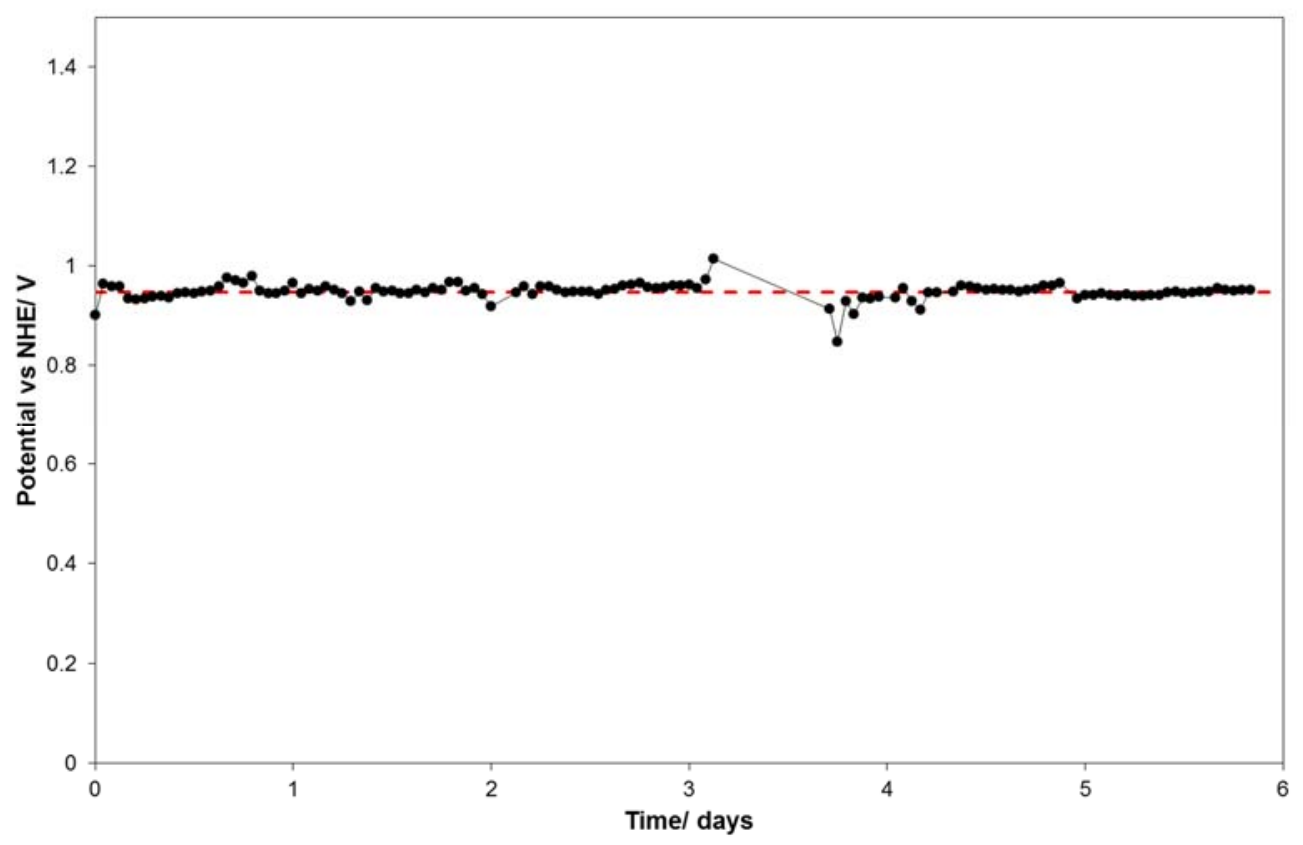

433

434 Figure 7: Six-day chronopotentiometry runs, at $1 \mathrm{~mA} \mathrm{~cm}{ }^{-2}$, recorded using the electrochemical cell 435 illustrated in Figure S1 with an n-Si/ $/ \mathrm{TiO}_{2} / \mathrm{Ir}$ photoanode,, , (under $455 \mathrm{~nm}$ LED irradiation, $6.5 \mathrm{~mW}$ $\left.436 \mathrm{~cm}^{-2}\right)$, with an electrolyte of $\left(0.5 \mathrm{M} \mathrm{H}_{2} \mathrm{SO}_{4}+3.5 \mathrm{M} \mathrm{NaCl}\right)$ and the current set at $1 \mathrm{~mA} \mathrm{~cm}{ }^{-2}$. The 437 average applied potential was $0.95 \mathrm{~V}$ (broken red line) 


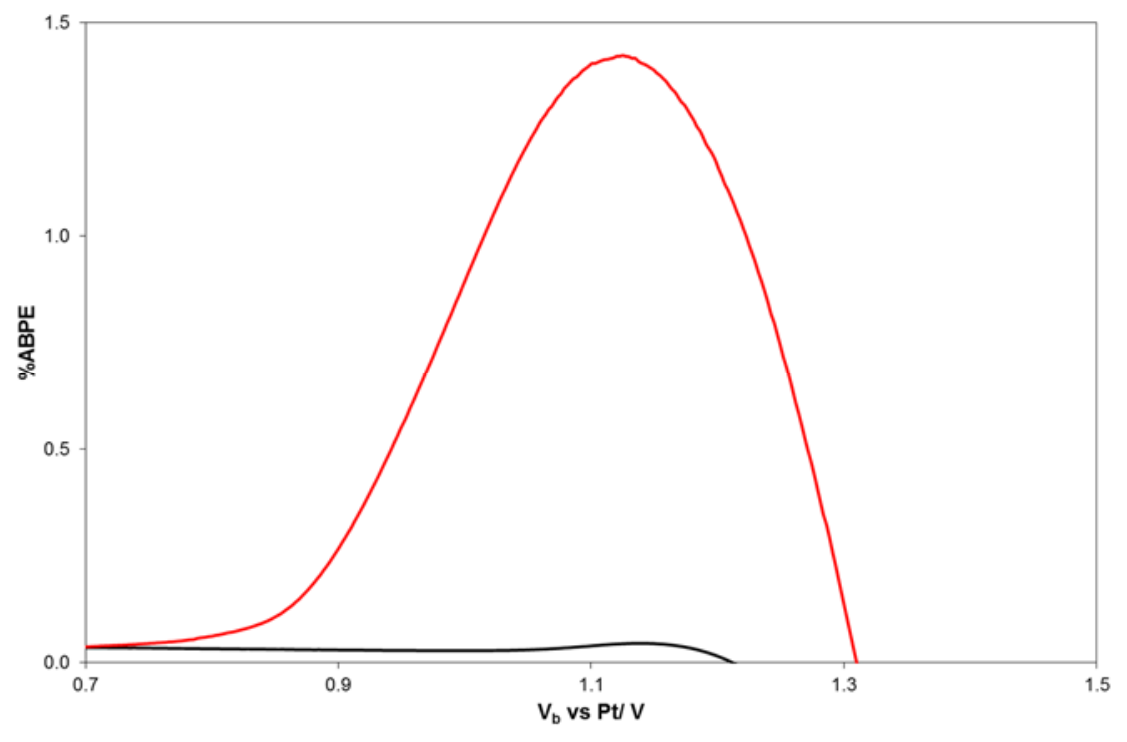

439 Figure 8: ABPE vs bias potential with respect to the Pt counter electrode, $\mathrm{V}_{\mathrm{b}}$ plot for the $\mathrm{n}-\mathrm{Si} / \mathrm{TiO}_{2} / \mathrm{Ir}$ 440 photoanode under 1 sun illumination in $0.5 \mathrm{M} \mathrm{H}_{2} \mathrm{SO}_{4}$ (for water oxidation - black line) and in $0.5 \mathrm{M}$ $441 \mathrm{H}_{2} \mathrm{SO}_{4}$ plus $3.5 \mathrm{M} \mathrm{NaCl}$ (for chloride oxidation - red line) 